\title{
ARE WE POST-JUSTIFICATION? STOUT'S CASE FOR SELF-KNOWLEDGE, POLITICAL JUSTIFICATION AND PUBLIC PHILOSOPHY
}

\author{
ESTAREMOS NA ÉPOCA DA PÓS-JUSTIFICAÇÃO? O ARGUMENTO \\ DE STOUT A FAVOR DO AUTO-CONHECIMENTO, DA \\ JUSTIFICAÇÃO POLÍTICA E DA FILOSOFIA PÚBLICA
}

Deven Burks* deven.burks@uni.lu

\begin{abstract}
Must the participant to public discourse have knowledge of her beliefs, attitudes and reasons as well as belief-formation processes to have justified political belief? In this paper, we test this question with reference to Jeffrey Stout's (2004) approach to public discourse and public philosophy. After defining selfknowledge and justification along the lines of James Pryor (2004), we map thereon Stout's view of public discourse and public philosophy as democratic piety, earnest storytelling and Brandomian expressive rationality. We then lay out Brian Leiter's (2016) naturalistic critique of public philosophy as "discursive hygiene" to see whether Stoutian public philosophy survives the former's emotivist-tribalist gauntlet. Lastly, we find that Leiter's critique proves less radical than it may appear and requires the moderating influence of a public philosophy like Stout's. All in all, Stoutian public discourse and public philosophy powerfully illustrates a strong, necessary connection between self-knowledge and political justification. Post-truth is not post-justification.
\end{abstract}

Keywords: self-knowledge; political justification; public philosophy; public discourse; Jeffrey Stout.

Sumário. Será que quem participa no discurso público tem de ter conhecimento das suas crenças, atitudes e razões, bem como dos processos de formação de crenças, de forma a ter crenças políticas justificadas? Neste artigo, testamos esta questão tendo como referência a abordagem de Jeffrey Stout (2004) ao discurso público e à filosofia pública. Depois de definirmos auto-conhecimento e justificação seguindo James Pryor (2004), aplicamos a perspectiva de Stout do discurso público e da filosofia pública como piedade democrática, narração honesta e racionalidade expressiva brandomiana. Em seguida, apresentamos a crítica naturalista de Brian Leiter (2016) à filosofia pública como "higiene discursiva" para determinar se a filosofia pública tal como a concebe Stout sobrevive ao desafio emotivista-tribalista daquele. Finalmente, concluímos que a crítica de Leiter é menos radical do que poderia parecer e requer a influência moderadora de uma

\footnotetext{
* University of Luxembourg.
} 
filosofia pública como a de Stout. Afinal, o discurso público e a filosofia pública que Stout defende ilustram de forma poderosa uma conexão forte e necessária entre auto-conhecimento e justificação política. A pós-verdade não é pós-justificação.

Palavras-chave: auto-conhecimento, justificação política, filosofia pública, discurso público, Jeffrey Stout.

\section{o. Introduction}

By many accounts, we are inhabitants of a post-truth world. Though truth and justification are separate notions, the question arises whether post-truth does not also entail a post-justification era. Indeed, in a world in which the person may say whatever she pleases, be it untrue or unjustified, it is unclear what role might remain for public philosophy. While this question surpasses the scope of a paper, we hope to make a contribution to the literature on political justification and public philosophy by exploring whether some form of self-knowledge is necessary thereto. To that end, we shall proceed in four parts. We shall begin by defining the notions of self-knowledge and justification pertinent to our enquiry and by setting out four versions of the link between self-knowledge and justification. In the second part, we shall lay out Jeffrey Stout's (2004) vision of public philosophy and the way in which it incorporates the relevant notions of self-knowledge and justification in the guise of "democratic piety", earnest storytelling and Brandomian expressive rationality. Thereafter, our attention will shift to Brian Leiter's (2016) critique of public philosophy from the twofold perspective of emotivism and tribalism, a critique which prima facie undercuts Stoutian public philosophy. Finally, we shall examine whether Stout's version of public philosophy is capable of turning Leiter's critique. In the end, we find that Leiter's critique proves less radical than it may appear and requires the moderating influence of a well-framed public philosophy like Stout's. All in all, a post-truth world may still have room, even a need, for justification and public philosophy.

\section{Defining self-knowledge and political justification}

What relation might obtain between self-knowledge and political justification? Certainly, any answer thereto will depend on the precise understanding of self-knowledge and political justification at issue. The kind of self-knowledge in which we are interested, while introspective, is not that of the 
person's senses or pain. Rather, we are concerned with the person's knowledge of her own beliefs, attitudes, reasons and history and the extent to which such knowledge may be more or less elaborate. Crudely, self-knowledge might come in two types. Whereas "thin" self-knowledge designates the person's having knowledge of (a set of) her own beliefs, attitudes, reasons and history, "thick" selfknowledge involves knowledge of the upstream processes (further beliefs, attitudes, reasons and history) at work in the formation of (a set of) her own beliefs, attitudes, reasons and history. By extension, the same distinction applies to the person's knowledge of others: "thin" other-knowledge is secured by the person's knowledge of (a set of) another's beliefs, attitudes, reasons and history while "thick" other-knowledge comes with the person's knowledge of the upstream processes (further beliefs, attitudes, reasons and history) at work in the formation of (a set of) another person's beliefs, attitudes, reasons and history.

In parallel, we propose an understanding of justification which largely follows Pryor (2004). ${ }^{1}$ For the latter, justification admits of two basic distinctions: 1.) "what you have justification to believe, and what you're rationally committed to believe by beliefs you already have" (Pryor, 2004, p. 363); 2.) "having justification to believe something, and having a belief that is justified or wellfounded" (Pryor, 2004, p. 365). By 1.), Pryor highlights the relation which obtains between two or more beliefs when the person thinks to have "decisive justification" to believe $p$ (Pryor, 2004, p. 364). If decisive justification for belief $p$ is congenial to a further belief $q$, then decisive justification for $p$ rationally commits her to the further belief $q$. If, on the contrary, decisive justification for belief $p$ rules out a further belief $q$, then decisive justification for $p$ rationally commits to her reject the further belief $q$.

\footnotetext{
${ }^{1}$ We should make clear from the outset that Pryor (2004) elaborates a twofold notion of justification with regards to Moore's paradox. Consequently, his text and examples bear largely on perception and perceptual evidence. We are, however, concerned with political justification. One may reasonably wonder whether we are right to cross-apply his nominally perceptual account to the political. In response, we shall point out only that, on one hand, there is no a priori conceptual reason to rule out general features which concern all instances of justification, and, on the other, Pryor's "justifiable"/“justified” distinction maps onto political justification just as well as onto perceptual. See infra. for examples to this effect. Furthermore, we will take this opportunity to emphasize that our account of the relation between self-knowledge and political justification is Pryorian rather than Pryor's own and that any distortions which we introduce therein are naturally our own. It bears mentioning that Pryor does not explicitly address the issue of self-knowledge though it appears indirectly in text and references.
} 
To these relations, "rational support" and "rational opposition", Pryor adds a third relation of interest, "rational obstruction" (idem.), wherein decisive justification for the belief $p$ undercuts a further belief $q$. More precisely, the decisive justification for the belief $p$ undermines the decisive justification which might count in favour of the further belief $q$. The author cites the case of defective colour perception: decisive justification for the person's belief that her perception is colour-deficient would undercut decisive justification for her belief that she perceives a given colour at any particular moment. A more political example might be as follows: decisive justification for the person's belief that the mass media are partisan or biased would undermine decisive justification for her belief that she obtains undistorted information at any given time. In short, the tension is at the level of grounds rather than content, as was the case for "rational opposition". Any of these three relations between beliefs may obtain within the person's mental economy without the decisive justification actually attaining the status of justification. It is enough that the justification appears decisive enough to provoke rational commitment of one form or another. Wherefore the importance of Pryor's distinction between justification and rational commitment.

The second distinction can be summarized as follows: that between a belief's being justifiable in virtue of an existing justification in the world and a belief's being justified in virtue of a justification's application to that belief. To put the point differently, consider that justification for a "belief $p$ " amounts to "reasons $r$ " which one might have for holding a "belief $p$ ". If one does not base one's "belief $p$ " on those "reasons $r$ " or opposes thereto other reasons or beliefs, then the "belief $p$ " is not justified, though potentially justifiable. Only when a.) one has justification for a "belief $p$ " and b.) one bases the "belief $p$ " on those "reasons $r$ " and c.) one has no other reasons or beliefs which rationally commit one to an opposed belief (i.e. rational opposition or obstruction) is the "belief $p$ " then justified rather than merely justifiable. More simply, having possible justification for a "belief $p$ " comes apart from being justified in having the "belief $p$ ". When the latter obtains, we will refer to the person's being "P-justified”.

Extending these distinctions to political justification consists in transposing the above structures onto recognizably political beliefs. To take but two examples, consider the following political beliefs: a progressive income tax is just; current 
electoral systems are unjust. Following Pryor, one might have justification for the belief that a progressive income tax is just while failing to have the belief itself due to ignorance, doubt, weakness of will, or conflicting beliefs. Perhaps the person has access to scholarly findings or political principles which justify that belief but simultaneously believes that scholarly findings are politically compromised, in which case the belief is justifiable rather than justified. Likewise, a belief that current electoral systems are unjust will only be justified when one has justification therefor, bases belief thereon and has no conflicting rational commitments. To reprise the first example's structure, the person has access to scholarly findings or political principles showing that the electoral system is unjust, bases her belief thereon and has no conflicting rational commitments as to the electoral system's justice.

So far, so good. It may, however, seem that an emendation is in order. For Pryor's breakdown of justification and rational commitment, justifiable belief and justified belief remains within a passive framework, even upon transposition. In contrast, political justification, when considered in the form of public discourse and justifying beliefs to others, moves us to an interpersonal and active setting. In this case, successful political justification might take either of the following forms: transmitting a justified belief from one person to another; adapting a belief or justification thereof to another's "cognitive context" to elicit the latter's recognition. ${ }^{2}$ Both cases prima facie preserve thin and thick self-knowledge requirements: one's expression of a justified belief must retain the relation between beliefs and reasons which render it justified on the interpersonal level.

Put differently, whether the person seeks another's adoption or recognition of a given belief, the belief to be adopted or recognized must stand in the same relation to justifying reasons if it itself is to be justified rather than merely justifiable. Moreover, another's adopting or recognizing a justified belief may require the person to know something of the other's cognitive context if she is to succeed in having the belief adopted or recognized. In this instance, it will be important for the person to have thin and thick other-knowledge: knowledge of

\footnotetext{
${ }^{2}$ By this term, we intend a person's relation to a personal history in the broader historical setting of a given time, place and culture. Though not his own term, its formulation is inspired by Stout (1988).
} 
the other's beliefs, attitudes, reasons and history; knowledge of the upstream beliefs, attitudes, reasons and history at work in the development of the former.

Nonetheless, it should be asked whether one can have political justification without self-knowledge. The properly amended Pryorian account seems to require self-knowledge for political justification insofar as one must be aware of one's "belief $p$ " and of any other reasons or beliefs which commit oneself to opposed positions. Otherwise, one might simply have a justifiable belief without that belief itself attaining "justified" status. Nevertheless, there are cases in which justification seems to proceed without self-knowledge, thin or thick. One prominent counter-example might be the Rawlsian original position for which, to arrive at a conception of justice for the distribution of primary goods in society or the evaluation thereof, the person has no knowledge of her preferences or beliefs ahead of the resultant distribution (Rawls, 1971). In short, the person would have access to neither the decisive beliefs, attitudes, reasons or history nor those upstream thereof. Consequently, the lack of self-knowledge would in no way hinder political justification and might even facilitate consensus. 3

That said, one may reject this depiction as misleading for several reasons. On our Pryorian account of political justification, the class of "beliefs $p$ " and "reasons $r$ " may be suitably narrowed such that the little which one knows about oneself figures all the same in the justified belief. After all, a person in the original position knows at minimum that she is: a moral person with a sense of the good as well as a sense of justice; a party to society as a system of cooperation; a being in need of certain primary goods. If such pieces of knowledge, however "thin" these may be, serve as justifying reasons to the person's "belief $p$ " and are consciously adopted as such, then thin and thick self-knowledge may nevertheless obtain. Conversely, if such knowledge is not applied to justify the person's "belief $p$ ", then that belief may be justifiable rather than justified. In short, though the original position limits the kinds of self-knowledge available to the person therein, she may still stand in the right formal relations to her beliefs,

\footnotetext{
${ }^{3}$ This consensus-facilitating quality has received some support in the empirical literature. $C f$. Frohlich, Oppenheimer, and Eavey (1987).
} 
attitudes, reasons and history, however thinly conceived. Nor does their thinness make the necessity of self-knowledge for justification merely trivial.

Provisionally, this framework leaves us with four possible answers to our starting question, namely, whether self-knowledge is necessary for political justification:

Strong and thick version: Thick self-knowledge is necessary for political justification.

Strong and thin version: Thin self-knowledge is necessary for political justification.

Weak and thick version: Thick self-knowledge is important for political justification.

Weak and thin version: Thin self-knowledge is important for political justification.

\section{Stout on self-knowledge and justification: piety, storytelling and expressive rationality}

In contrast to Pryor, Jeffrey Stout has a more elaborated, if not systematic, view of the relation between self-knowledge and justification, particularly its political subspecies. In this section, we aim to determine the extent to which Stout might draw on a Pryorian framework in his treatment of self-knowledge and justification. Stout's (1988; 2004) view holds that justification, broadly conceived, proceeds or should proceed with a view to the person's "cognitive context”, i.e. her relation to a personal history within the broader historical setting of a given time, place and culture. Insofar as justification is indexed to a given context and successful justification turns on knowledge of that context and a given context includes the person justifying and her horizon of reasons, then justification's success is indexed to knowledge of the person justifying and her horizon of reasons. When justifying one's views to another, justification then entails thick self-knowledge (strong and thick version). Likewise, it calls for thick-other knowledge in situations where one aims to have another adopt or 
recognize a "belief $p$ ". Hence, Stout's account preserves the broad strokes of a Pryorian framework. 4

Over four books, Stout attempts to work out the insight that justification is indexed to a cognitive context. Political justification receives its most theoretically complete treatment in Stout (2004) wherein the author confronts the reader with a view of political deliberation as earnest reason-giving. In short, when engaged in political deliberation, participants thereto should give their real reasons for a given political position, whether those reasons be tied to a political conception of justice or to a comprehensive doctrine, religious, philosophical or moral (Rawls, 1993). As Stout puts it, "cultivate the virtues of democratic speech, love justice, and say what you please” (Stout, 2004, p. 85). On one hand, we should not require persons to voice reasons other than their own. 5 On the other, he deems it epistemologically unreasonable on our part to maintain that persons giving comprehensive beliefs and reasons for a political position be excluded from deliberation as such beliefs and reasons can be responsibly held or P-justified. ${ }^{6}$ Recall that a "belief $p$ " is P-justified only when a.) one has justification for a "belief $p$ " and b.) one bases the "belief $p$ " on those "reasons $r$ " and c.) one has no other reasons or beliefs which rationally commit one to an opposed belief (i.e. rational opposition or obstruction).

Naturally, for the person to voice those beliefs and reasons and to be entitled thereto, she must first know what they are. This requires the person's taking stock

\footnotetext{
${ }^{4}$ For a more complete overview of justification, see notably Stout (1988), pp. 28-30 and Stout (2004), pp. 231-237.

${ }^{5}$ This is a requirement which Lafont (2013) has dubbed, with reference to Habermas' work on religion, as "the right of all democratic citizens to take their own cognitive stance in public deliberation" (p. 243, emphasis in original).

${ }^{6}$ While Stout prefers the language of responsibly holding a belief or "epistemic entitlement" (Stout, 2004, pp. 65-73), these notions demonstrate considerable similarity with being P-justified. A person who is epistemically entitled to a belief has potentially justifying reasons therefor, is aware of these reasons as being such and conforms to her broader epistemic responsibilities (Stout, 2004, p. 71). In this, a Pryorian account and Stout's approach are similar, and we will use "epistemically entitled" and "P-justified" interchangeably. Nevertheless, the authors are not without their differences. Most notably, they would charge each other with confusion over whether it is a "belief $p$ " which is justified or whether it is the person, who in holding "belief $p$ ", is justified. Stout is keen to differentiate the way in which a person "is justified in believing a claim if he or she is entitled to be committed to it, given his or her discursive context and cognitive conduct" from the way in which a belief or claim is "justified in some discursive context if everyone in that context is justified in believing it" (Stout, 2004, p. 99). Pryor would likely see therein two situations in which the same conditions apply to justification, the latter's context-wide justification being merely an aggregation of the former's person-by-person instances. In the end, whether one adopts Stout's distinction or rebuffs it as confusion does not alter the underlying structure of entitlement.
} 
thereof, for which the person may avail herself of "democratic piety" (Stout, 2004, p. 9). Stout understands this notion as the person's making an inventory of the different moral and social sources responsible for the shape of her life at a given moment in time and giving appropriate expression thereto. In that these intertwine with the person's history, they provide her with a horizon of reasons which may justify or fail to justify her political position (the state of "being justified") and which she may use to justify, successfully or unsuccessfully, her political position (the act of "justifying”). In a word, the person's contribution to public discourse should manifest in some form the different social resources at work in her ethical and political reasoning. Notably, that form may vary depending on the context. Stout refers most often to a "democratic" context, an "Emersonian" sub-context:

[F]rom a democratic point of view, the only piety worth praising as a virtue is that which concerns itself with just or fitting acknowledgment of the sources of our existence and progress through life (...) Imagining or conceiving of those sources and choosing ethically and aesthetically apt expressive means of acknowledging dependence on them are both things for which an Emersonian poet or essayist expects to be held responsible discursively (Stout, 2004, p. 30).

Indeed, these contexts are themselves capable of greater precision depending on the moral and social sources at issue. On several occasions, Stout point the way towards democratic piety by describing the moral and social sources on which he himself depends for his moral and political reasoning. To take but one example:

In the days of my adolescent sublime, Martin Luther King, Jr., was the hero of my humanitarian cause, and Jesus was one of three personifications of my loving divinity. Nowadays things have become more complicated, because I have come to know more about these figures of virtue than their hagiographers and publicists wanted me to know (...) Love and justice remain virtues (...) but now the relation between the persons and the virtues is more complicated. It requires a different, less doctrinal, more improvisational kind of explication. To the extent that King and Jesus exemplify virtues in my imaginative life, they now do so imperfectly and defeasibly. I therefore need an open-ended way to think the relation through, as it were, from both sides at once. Neither doctrine, nor 
principle, nor system, nor overarching plot, knowable in advance, constrains the course of thinking (...) We all have our examples, after all, and we all make something of them sooner of [sic] later. We do not, however, make the same thing of them. Neither do they make the same thing of us (Stout, 2004, p. 173).7

Herein, we see democratic piety at work. Stout tells his story and takes inventory in "critical" fashion: recognizing moral and social sources as such; refusing one-sided tendencies to nostalgia, wishful thinking or idealization; introducing between person and sources two-sidedness via reflection, research and questioning. Just such an earnest stocktaking leaves the person ready to advance reasons, be it in the form of structured argument or personal storytelling. 8

Indeed, one reasonably wonders how the person may in public discourse articulate for the audience her sources, reasons and commitments and, hence, her cognitive context, of which she will have taken stock via democratic piety. Stout's (2004) clearest answer, worked out in greater detail in Stout (2010a), lies in the idea that persons should voice their deepest reasons and personal histories. In criticizing both universalist and particularist thinkers, he remarks "that neither [Seyla Benhabib nor Stanley Hauerwas] has imagined the possibility, let alone the desirability, of a loosely structured democratic conversation in which variously situated selves tell their own stories on their own terms” (Stout, 2004, p. 179).

In other words, apart from structured argument, a key way for epistemological formations such as beliefs, attitudes, reasons and history to come to light consists in the person's telling her own story and development. Indeed, storytelling enables the audience better to grasp the real horizon of reasons and commitments within which the person is working (supposing that the person knows the story elements and tells it accurately and non-coercively). Moreover, not only should the person's right to self-expression and storytelling merit respect from the audience; her beliefs and reasons, as well as the person herself, deserve our respect, on the condition of their being P-justified. Certainly, whether we give

\footnotetext{
${ }^{7}$ For another example, see Stout (2004), p. 97.

${ }^{8}$ For a review of the deliberative democratic literature on rhetoric and storytelling as modes of deliberation, see Dryzek (2000), pp. 50-56, 62-70. For empirical analysis of one instance of discourse and modes of deliberation therein, see Bächtiger and Gerber (2014).
} 
such respect is another matter. Stout drives this point home when enjoining the audience to respect both the believer's right to express and the content expressed: "Insofar as they [those who differ from us religiously] do acknowledge that dependence [piety] appropriately, given their own conceptions of the sources of existence and progress through life, they may be said to exhibit an attitude that is worthy of our respect, if not our full endorsement” (Stout, 2004, p. 34).

Provided that the person abides by the virtue of democratic piety and appropriately takes stock of and reflects her context or beliefs, attitudes, reasons and history in discourse, the person merits our respect as a fellow interlocutor whose beliefs, attitudes, reasons and history are worth examining at greater length. All the more so in that such expression sets the audience up to unearth the beliefs, attitudes, reasons and history motivating the person to support a given position; it may also grant the person an opportunity at greater thin or thick self-knowledge through give-and-take with the audience. More importantly, listening to stories and according respect as due does not inevitably lead to a mere modus vivendi. By censuring them, not only do we "remain ignorant of the real reason that many of our fellow citizens have for reaching some of the ethical and political conclusions they do", but we "also deprive them of the central democratic good of expressing themselves to the rest of us on matters about which they care deeply" (Stout, 2004, p. 64). In so doing, we "lose the chance to learn from, and to critically examine, what they say", and they "have good reason to doubt that they are being shown the respect that all of us owe to our fellow citizens as the individuals they are" (idem.).

Far from isolating the audience into incommensurable spheres of discourse, Stout's take on respect lays the first stepping stone to critical examination and exchange of beliefs, attitudes, reasons and history. For without the knowledge afforded by listening and respect, critical examination would otherwise have no object on which to work. And, without materials for examination, no way out of an impasse will present itself to participants in public discourse, perhaps even more so than in cases of deep disagreement.

In addition, respect serves a second, more practical purpose. If, by listening to stories, respect may grant the listener knowledge of the person's real beliefs, attitudes, reasons and history informing a given position (thereby promoting 
other-knowledge), this practical exercise also makes the person more amenable to the subsequent exchange of reasons with the audience. In one important sense, through respect, the audience may recognize the person as a full-fledged member of public discourse and, given the necessary conditions, as P-justified in believing that to which she has just given expression. This comes out even more strongly in Stout (2010a), a case-study of broad-based citizens' organizing centring on "house meetings" and "one-on-ones", i.e. "individual conversations" and "small gatherings". 9

Yet a person herself may not always be able to take stock of or to draw out what follows from the critical inventory made during the phase of piety and aired out in the phase of storytelling. Accordingly, the person may require a spokesperson, be this a philosopher to work out the inferential commitments underlying the reasons for her political position or a community organizer to extract the issue taking shape therein. In both instances, another will bring greater clarity to what links certain commitments or issues. Wherefore Stout's view that public philosophy consists in making explicit and scrutinizing the commitments and norms implicit in public discourse and reasons: in short, it requires an exercise in Brandomian "expressive rationality" (Stout, 2004, pp. 1214; Brandom 1994).

More concretely, this may entail taking norms or reasons, often expressed as material inferences "given $x$, I shall $y$ " for which we ordinarily acknowledge $x$ as a legitimate premise for the conclusion $y$, and working out the premise needed to make them formally valid (Stout, 2004, pp. 188-190). So, to statements like the following: "(a) Going to the store is my only way to get milk for my cereal, so I shall go to the store; (b) I am a lifeguard on the job, so I shall keep close watch over the swimmers under my protection; (c) Ridiculing a child for his limp would humiliate him needlessly, so I shall refrain from doing so"; we would need to append further premises: "(a) a statement expressing my desire to have milk for my cereal; to (b) the conditional that if I am a lifeguard, it is my responsibility to

\footnotetext{
${ }^{9}$ For an overview of these organizations and interactions, see Stout (2010a), pp. 2-3; for a detailed examination of one house meeting or small gathering, see Stout (2010a), pp. 151-156.
} 
keep a close watch over the swimmers under my protection; or to (c) the principle that one ought not to humiliate people needlessly" (Stout, 2004, p. 188). ${ }^{10}$

This exercise presents the "advantage of putting the formerly implicit material inferential commitment in the explicit form of a claim, which in turn allows it to be challenged or justified inferentially in light of other considerations" and takes on still greater importance "when conflicts arise among different material inferential commitments that we have undertaken" (Stout, 2004, p. 189). Hence, Stout's account of expressive rationality incorporates a requirement like that of examining rational commitments on Pryor's view in order to arrive at epistemic entitlement or P-justified belief.

More important for our purposes is the way in which working out inferential commitments proves both means and hindrance to the link between selfknowledge and political justification outlined above. For, if our capacity for selfknowledge may help to secure the justified quality of our political positions by working out the entailments of our beliefs, our cognitive failings may also hinder arriving at (thick) self-knowledge and, hence, P-justified political belief. Such that the person may need to rely upon the public philosopher to arrive indirectly at the thick self-knowledge necessary for a P-justified political belief. Indeed, the person may lack entirely the expressive resources necessary to render those commitments explicit or even the cognitive resources necessary to work the latter out (Stout, 2004, p. 193).

Before concluding this section, it will be helpful to consider, with reference to our examples above, how Stoutian self-knowledge and political justification intersect in democratic piety, personal storytelling and expressive rationality and create a need for a public philosophy. In the first case, a person may have the belief that a progressive income tax is just but initially prove unable to say why she holds that belief. To that end, she would, on Stout's approach, take stock of the moral and social sources informing her belief, be those moral beliefs about fairness or religious beliefs about charity. From there, she would find the mode of expression most fitting for sharing her belief and framing it with reasons. That mode of expression may include personal storytelling, e.g. her own experiences

\footnotetext{
${ }^{10}$ For Brandom's exposition of this point, see Brandom (1994), 243-253 and Brandom (2000), ch. 2.
} 
as a member of a society with a progressive income tax. Finally, both prior to and during public discourse, she and others would work out whether her beliefs and reasons commit her to other beliefs and reasons, and, if so, which. In this way, she might arrive at a P-justified political belief on the justice of a progressive income tax.

If the above stands as a successful, direct instance of Stoutian political justification, we may consider a second instance wherein political justification succeeds, though only indirectly. Specifically, a person may have the belief that the current electoral system is unjust but initially prove unable to say why she holds that belief. Accordingly, she would then take stock of the moral and social sources informing her belief, perhaps in the form of moral beliefs about autonomy or religious beliefs about temporal power. If she is capable of this inventory, she may nonetheless be unable to frame her belief in terms of deeper beliefs or reasons or to work out the various commitments to which her belief commits her. In such a case, she would fail to achieve thick self-knowledge and, on Stout's view, require a public philosopher's help to work out her upstream beliefs, reasons and commitments in order to attain a P-justified political belief on the injustice of the electoral system.

Finally, it remains to be seen how this impacts our main question on the relation between self-knowledge and political justification. In this section, we have laid out Stout's view of self-knowledge and justification in the threefold form of democratic piety, personal storytelling and expressive rationality. We have further shown the ways in which that threefold form resembles the Pryorian framework, necessitates thick self-knowledge for political justification and thereby subscribes to the strong and thick version of the relation between selfknowledge and political justification. Furthermore, we have seen how Stoutian justification creates a need for public philosophy. For, if public philosophy advances self-knowledge in public discourse, it also advances political justification. On the other hand, public philosophy's advancing self-knowledge hinges on thick other-knowledge and on the person's taking responsibility for how she forms beliefs before and after the public philosopher's work. Otherwise, the public philosopher's work on the raw material of piety and storytelling and on logical entailments of the beliefs, attitudes, reasons and history exposed therein 
is for nought. We may likewise question whether public philosophy and its practitioners are themselves capable of articulating thick other-knowledge and thereby advancing indirect self-knowledge. Both hinge on public philosophy's efficacy. If public philosophy and public philosophers are incapable of occupying this role, then Stout's view of justification is mistaken or misleading.

\section{Leiter on the paradoxes of public philosophy: Emotivism and tribalism}

Brian Leiter would likely suspect just this about Stout's view. Leiter (2016) scrutinizes any public philosophy which sees itself as "contribut[ing] philosophical insight or knowledge or skill to questions of moral and political urgency in the community in which it is located" (p. 51). As this prima facie concerns Stout's appeal to public philosophy as an exercise in expressive rationality, Stout must then wrestle with the two paradoxes laid out by Leiter. The first holds that what expertise philosophers may "offer can not [sic] consist in any credible claim to know what is good, right, valuable, or any other substantive normative proposition that might be decisive in practical affairs (Leiter, 2016, p. 53).

The second paradox builds off the first. If philosophers do not bring to public discourse substantive normative knowledge, they may nevertheless offer "a method or way of thinking about contested normative questions that they offer" (idem., emphasis in the original). In this method, public philosophers engage in an activity quite close to Stout's “expressive rationality”. Namely, such philosophers set out from a set of normative commitments and "work out their entailments, demonstrating claims of the form, 'If you believe $\mathrm{X}$, then you ought to believe Y,' and, 'If you believe Y, you should not do Z.' (idem.). In so doing, they engage in "discursive hygiene" by which the author denotes "parsing arguments, clarifying the concepts at play in a debate, teasing out the dialectical entailments of suppositions and claims" (idem.). The paradox lies in that, while public philosophers may claim to bring discursive hygiene to public discourse, that hygiene "plays almost no role in public life, and an only erratic, and highly contingent, role in how people form beliefs about matters of moral and political urgency" (Leiter, 2016, p. 55). 
If, as suggested above, we associate Stout's view of public philosophy as expressive rationality with discursive hygiene but find ourselves obliged to admit the lack of discursive hygiene in public discourse, we might nevertheless maintain that interlocutors are amenable to the work of "discursive hygiene" either at their own or another's behest. Leiter forestalls this possibility insofar as the psychological phenomena of emotivism and tribalism should temper our optimism about the state of public discourse and public philosophy as "discursive hygiene". These phenomena require further explanation.

Of the first phenomenon, emotivism, Leiter holds that it acts as a limiting case on public philosophy as "discursive hygiene". Notably, Leiter associates emotivism with Charles Stevenson's seminal position which Leiter presents as follows: "Ethical disagreements are at bottom a function of disagreement in attitudes, rather than disagreements about beliefs" (Leiter, 2016, p. 53). To this, he adds that "the connection between particular facts and our attitudes is just a contingent psychological/causal fact", to wit "it is just a psychological fact about many creatures like us that if our beliefs change, our attitudes often change too" (Leiter, 2016, p. 54, emphasis in original). ${ }^{11}$ On this reading, public discourse may take the form of conflict between either attitudes or beliefs. If between beliefs, though rare, then the conflict may be brought to an end by ensuring convergence between beliefs. If between attitudes, then the conflict admits of no clear-cut solution in that attitudes do not seem reason-responsive in the same way as beliefs.

Certainly, we may allow that our beliefs influence our attitudes; we cannot, however, maintain with any certainty how or which beliefs influence attitudes. For we are simply unable to plot the causal mechanisms by which such changes are effected. Moreover, attitudes may alter in light of beliefs which we ordinarily deem "ethically irrelevant" because "self-serving" (Leiter, 2016, pp. 54-55). All in all, our inability to pin specific attitude changes to certain belief changes "includes

\footnotetext{
${ }^{11}$ It bears mentioning that the author also finds emotivism's main thesis in principle compatible with "discursive hygiene" (Leiter, 2016, p. 53). In short, both could in theory exercise causal power in belief-formation. In practice, emotivism tends, however, to exclude the causal efficacy of "discursive hygiene".
} 
changes in belief about the logical or inferential relations between beliefs or between beliefs and attitudes" (Leiter, 2016, p. 55).

This should be worked out more concretely. Reprising our second example, a person may have the belief that the electoral system is unjust due to her moral beliefs about autonomy, religious beliefs about temporal power or her underlying social attitudes about democracy and politics. To change her belief that the electoral system is unjust, another person might try one of several strategies. The latter may appeal to ethical considerations counter to her moral or religious beliefs (e.g. the temporal-spiritual power divide is necessary), to unethical considerations about that which best advances her self-interest (e.g. the electoral system best preserves her own or group's freedom of belief) or to opposed social attitudes (e.g. a renewed sense of public service). Supposing that, following the exchange, the person holds the belief that the electoral system is just, Leiter's point is that neither she nor the other will be able, introspectively or conceptually, to ascribe the change in belief to a given strategy or the specific considerations advanced therein rather than non-discursive factors.

On Leiter's account, there are thus no rules, inferential or otherwise, governing the transformation of and causal interaction between beliefs and attitudes. A given belief may provoke change in another belief or attitude without one's being aware thereof. Likewise, one may attribute change in a given belief to some other belief or attitude but do so in error. Even if beliefs have causal traction over attitudes, this casts doubt on a.) whether thin knowledge of one's beliefs can induce changes in one's attitudes and b.) whether thick knowledge of how one came by those beliefs can bring on change in one's attitudes. For the author, there is be no conceptual apparatus capable of reliably tracking or predicting those changes.

Leiter highlights two examples to further his claim: the 2014 Steven Salaita controversy at the University of Illinois Urbana-Champaign suggests that discursive hygiene on clear-cut legal norms can fail; Jonathan Haidt's 2001 "incest experiment" tests a social intuitionist model of practical reasons, "according to which in most ordinary situations, moral judgments are produced by emotional or affective responses, the reasons adduced in their support being post-hoc: they do not explain the judgment, as evidenced by the resilience of the 
judgment even in the face of the defeat of the proffered reason" (Leiter, 2016, pp. 57-58).12 While such examples do not disprove the effect of discursive hygiene on moral and political judgments, they act as a limit to public philosophers' optimism.

With this, Leiter's account of emotivism is in place: a person's moral and political beliefs, reasons and judgments are a function of emotional attitudes or affective responses, and changes therein are subject to no systematic exposition. Since the person is mistaken on the real reasons and processes behind her "belief $p$ ", that belief cannot be P-justified. At this point, the author is ready to move to the second limiting case to "discursive hygiene" in public discourse. If "prejudice and bias are dominant forces in human life", this owes to "tribalism", whereby Leiter means "the propensity of creatures like us to identify with those 'like themselves,' and to view others as unacceptably different, deficient, depraved, and perhaps dangerous" (Leiter, 2016, p. 59).

Although the author sees in tribalism "the dominant force in public life" (idem.) and sketches how it may determine whom the person deems worthy of moral concern in virtue of their similarity or dissimilarity, more can be said of how tribalism directly impacts discursive hygiene and public discourse. First, the person tracks not the inferential relation between beliefs, attitudes and reasons highlighted by discursive hygiene but, instead, her own similarity with other interlocutors. Second, it predisposes the person to adopt divergent discursive stances towards those interlocutors similar and dissimilar to her. While she will be more likely to accept a similar person's beliefs, attitudes, reasons and history as good and to deem the latter a rational actor or a locus of human dignity, she will be more likely to dismiss a dissimilar person's beliefs, attitudes, reasons and history as bad and to view the other as less than a rational actor or a locus of human dignity.

If, as Leiter concedes, such tribalistic mindsets have somewhat given way with the rise of international and transnational bodies, the fact remains that such institutions as the United Nations and notions as universal human rights first

\footnotetext{
${ }^{12}$ That said, Brandom and Stout are also sensitive to rationalizing of this kind. See Brandom's discussion of acting with or for reasons (Brandom, 2000, pp. 83-84, 95-96). See infra. for Stout's breakdown of types of rationalization and opposition to same-sex marriage.
} 
emerged following horrendous, widespread conflict. To this end, Leiter contends that "argument played little or no role" therein; rather, such progress is to be attributed to "emotional revulsion at barbarity" (idem.). Linking this to his emotivist point on attitudinal recalcitrance, he remarks that "[ $\mathrm{t}]$ he key point, however, is that we philosophers must recognize that moral change depends fundamentally on the emotional attitudes of people, and that these attitudes tend in a strongly Tribalist direction" (Leiter, 2016, p. 60). For the author, this comes out most strongly in whom one considers deserving of one's moral concern: those with whom one feels an emotional connection, such as kinship, merit one's moral regard. All the same, we find that Leiter's main point might be extended to the discursive level: one's beliefs, attitudes and reasons are most responsive to pressure coming from those who are similar to oneself, yet those similar to oneself are precisely those least likely to pressure one on one's beliefs, attitudes and reasons.

To return to our first example, consider a person who holds the belief that a progressive income tax is just, be it for moral reasons about fairness, religious reasons about charity or social attitudes about wealth. Leiter's main point is that she will judge the taxation system fair insofar as it benefits those similar to herself and penalizes those dissimilar to herself, for the former, rather than the latter are worthy of her moral concern. At the discursive level, were another to challenge the person on her belief that the taxation system is just or on her attitudes or reasons supporting that belief, her likelihood of engaging the former's challenge and related beliefs, attitudes and reasons would hinge on the former's similarity with herself. In such conditions, she may not seek knowledge of her own beliefs, attitudes, reasons and history necessary to arrive at P-justified belief.

For his part, Leiter contends that public philosophers are most likely to broaden interlocutors' moral regard for other persons or beings when they appeal to interlocutors' emotions rather than to the inferential connections between beliefs, attitudes and reasons. Case in point, Peter Singer, perhaps today's foremost public philosopher, appeals to emotional attitudes with no deeper rational basis (i.e. the moral salience of suffering rather than species) and makes his argument most effectively when relying on "moral perception”, e.g. his grisly description of factory farming ( $c f$. Leiter, 2016, pp. 60-62). Similarly, Leiter sees 
the appeal to non-rational considerations such as "theoretical simplicity, methodological conservatism, and consilience" (Leiter, 2016, p. 60) as still more reason to temper our expectations for public philosophy. If public philosophers count on emotional attitudes and affective responses in lieu of discursive hygiene to do the philosophical heavy lifting, the author rightly wonders why we should expect better of lay audience members in public discourse.

Despite his vigorous contestation of discursive hygiene, Leiter does not mean to sound the death knell of all public philosophy. On the contrary, he marshals three considerations in its favour:

Being unable to contribute meaningfully to urgent ethical and political matters in no way diminishes the importance of finding an answer to those matters.

If we do not understand well the causal linkage between beliefs and attitudes at the time of discursive hygiene, this does not mean that discursive hygiene might not track the evolution of beliefs and attitudes. One should thus go on providing such hygiene.

Law, the discipline closest to philosophy, practices discursive hygiene and recognizes the need therefor in the sense that logical entailments can constrain attitudes when the time comes to rationalize the reasons proffered and the attitudes adopted. ${ }^{13}$

In this way, Leiter hopes to moderate the thoroughgoing critique of public philosophy which his treatment otherwise suggests. Indeed, it is worth emphasizing the most important lesson which the author draws from 3.). Namely, he contends that law has understood something which philosophy has not: rhetoric or "the art of persuasion apart from appeal to what follows from discursive hygiene" may play a predominant role in determining whether and what beliefs a person holds (Leiter, 2016, p. 63). Put differently, "belief fixation', the process by which certain beliefs take hold in the cognitive and affective economy of the mind and thus yield action, does not necessarily track evidential, inferential and logical relations that interest philosophers" (Leiter, 2016, p. 64).

\footnotetext{
${ }^{13}$ For lengthier exposition of these points, $c f$. Leiter (2016), pp. 62-63.
} 
If this suggests that philosophers aiming to provide clarity on ethical and political issues should add rhetoric to their argumentative toolbox, they must not abandon the careful work of discursive hygiene, for "rhetoric does not tell us what beliefs we should try to produce with our rhetorical tools" (idem., emphasis in the original). In a word, Leiter contends that philosophical argumentation must, at least at one level, track emotional attitudes and affective responses if it is to retain currency within public discourse. Before assessing whether this does enough to moderate Leiter's critique and whether Stout can take this requirement on board, it is worthwhile to step back and to take stock of whether and to what extent Leiter's account modifies the connection which we have sketched between selfknowledge and political justification.

His emotivist charge purports to show that the person first has an emotional or affective response to a given set of circumstances for which she only afterwards adduces reasons. This would cast doubt on her claim to thick self-knowledge in that she deceives herself on the processes behind that belief. As to her thin selfknowledge, if she is aware of her belief on a given political position, she nonetheless mistakes her immediate reasons therefor. Were she aware of the emotional source of her belief, she would recognize the adduced reasons as posthoc additions. Accordingly, her thin self-knowledge is incomplete in part because of the opaque character of the thick, and her belief is, at best, justifiable, though not P-justified.

What then of Leiter's tribalist charge? If emotional attitude or affective response determines political attitudes and emotive attitude or affective response is divided along tribal lines, then political attitudes are themselves divided along tribal lines. Such that the self-knowledge breakdown for the emotivist charge seems to cross-apply: while the person may know her belief on a position and the purported reasons for that belief, she also ignores how she came to hold the latter and what reasons genuinely support it. Again, thick and thin self-knowledge fail in that she ignores why she considers certain of moral concern rather than others, certain as offering valid beliefs, attitudes or reasons rather than others and her real reasons for judgments of worth and validity. Thus, her political position is at best justifiable in light of other considerations but not P-justified by way of her own beliefs. 
Given this failing of thick self-knowledge, Leiter could contend that we must forego thick self-knowledge since the person is constitutively incapable of recognizing the emotivist and tribalist cast of her attitudes, beliefs and reasons. Instead, we should apply pressure to thin self-knowledge through rhetoric and "moral perception" targeting the reasons adduced for a given belief. In the Pryorian terms outlined above, Leiter would, on this reading, play down the possibility of political justification in that few, if any, will hold P-justified (as opposed to justifiable) beliefs, however attached we might be to attaining Pjustified political belief. Does Stout have an answer to these challenges or is his view of public philosophy as expressive rationality condemned? For that matter, can Leiter both maintain such a thoroughgoing critique and hold out hope for public philosophy without some moderating influence?

\section{What role for Stoutian public philosophy in the face of Leiter's challenge?}

Certainly, Leiter's challenges to public philosophy as discursive hygiene are considerable, and no panacea is likely to be found therefor. Moreover, a full rebuttal thereof would swiftly surpass the scale of a paper. We will content ourselves then with sketching either of two tacks which Stout might use to bridge the gap between his public philosophy and Leiter's naturalistic critique.

The first consists, first, in reconciling post-hoc rationalization to selfknowledge and Stoutian public philosophy and, then, in managing one's discursive expectations accordingly. Stout (2010b) takes a step in this direction by elaborating a typology of opposition to same-sex marriage. More precisely, he outlines how the beliefs of religious opponents to same-sex marriage may be analysed with an eye to the role that reasons play in rationalizing their opposition. For those "sadistic homophobes" who use religious rationalization wittingly as a cover for the emotional attitude or affective response motivating their opposition, they are not tracking reasons for that opposition, and there is consequently little hope that they will react to pressure from reasons. In short, one should not hope to sway them through public philosophy, be it in the form of discursive hygiene or rhetoric. 
For those "unwitting homophobes" who use religious rationalization unwittingly as a cover for the emotional attitude or affective response motivating their opposition, neither are they tracking reasons for that opposition nor do they have any helpful thin self-knowledge, but there is hope that they will react to pressure from the right kind of reasons. That is, they may react to pressure in that they are hateful but unaware of their rationalizations as such and may otherwise consider themselves decent people, which would provide an argumentative foothold for rhetorical pressure, such as appeals to their decency or face-to-face interaction with a person whom they nominally condemn.

Finally, there are those "well-intentioned opponents" who, while not homophobic, have a negative emotional attitude or affective response and find religious teachings a plausible explanation therefor. For these opponents, "reasons are playing a greater role in the formation of their political position in the first place" (Stout, 2010b, p. 533). Accordingly, even if they are mistaken on the reasons for their opposition and are unaware of the upstream processes underlying their opposition (and so lack thin and thick self-knowledge), their opposition tracks or is keyed to reasons rather than affective responses or similarity with their own person. Hence, well-intentioned opponents are more likely to be responsive to pressure on the reasons for their opposition. One would have to "show them that their scriptural reasons for opposing same-sex marriage fail to cohere with other commitments they hold with equal or greater confidence" (idem.). Such rhetorical pressure may increase the chances of thin self-knowledge and open a progressive path towards thick self-knowledge through inventorying the person's religious sources, if not through exposing the upstream beliefformation processes of emotivism. In short, thick self-knowledge and political justification can accommodate a certain degree of post-hoc rationalization provided that interlocutors, public philosophers included, can distinguish the kinds of ill-intentioned, mis-intentioned or well-intentioned reasons adduced and adjust their expectations and interactions accordingly.

Notably, Stout (2010b) also suggests that one might call interlocutors' attention to the role which non-discursive factors play in upstream beliefformation. For an audience of mis- or well-intentioned opponents, if one were to call attention, for example, to how the distinction between genders and its 
importance to the division of labour and inheritance rules, this might also help move the discussion forward (Stout 2010b, pp. 533-534). All the same, changes in the social structure itself over time may do more to move the conversation along than discursive factors employed by public philosophy. In this way, Stout, like Leiter, deems changes in attitude in part attributable to non-discursive factors. In other words, Stout is aware, at least implicitly, of one challenge close to the emotivist, tribalist version posed by Leiter and is ready to adapt. ${ }^{14}$

Finally, if Stout admits that "the intuitions from which moral reasoning proceeds are not the same" in different social structures (Stout, 2010b, p. 534), that is, different social structures evince divergent emotional attitudes or affective responses, the author's insistence on pursuing discussion with mis- or wellintentioned opponents suggests that discursive hygiene may nonetheless play a role in public discourse by shedding light on the upstream belief-formation processes. ${ }^{15}$ What is then at issue is whether Stout accepts the scope of the problem traced by Leiter, namely that emotivism and tribalism are constitutive of all instances of attitude- and belief-formation and prima facie block thin and thick self-knowledge and justified political belief. Leiter's own attempts to moderate his critique and Stout's partial integration of post hoc rationalization suggest that it need not be so.

Turning now to the second tack, we contend that Stout could push Leiter on the conditions necessary to pursue the latter's vision of efficacious public philosophy. More simply, if the latter's critique is as thoroughgoing and effective in rebutting public philosophy as it appears, his own attempts to moderate that critique may require buttressing from an outside source. To that end, Stout could point to the way in which successfully applying rhetorical pressure depends in part on discursive hygiene and other-knowledge (either thick or thin). Put differently, the public philosopher or interlocutor may draw on discursive hygiene to arrive at (thin or thick) knowledge of the person's perspective or inferential commitments from which the former may identify the kinds of

\footnotetext{
${ }^{14} \mathrm{Cf}$. the enlightening discussion of the alternative popular modes of moral inculcation and development (e.g. "poems, novels, essays, plays, and sermons" (Stout, 2004, p. 163) and their importance relative to moral theory (Stout, 2004, pp. 162-168).

${ }^{15}$ In truth, whether Leiter intends to do so, his own exposition of the paradoxes of public philosophy may serve a similar purpose in the end by bringing attention to the way in which tribalism and emotivism shape beliefs, attitudes and reasons.
} 
reasons, at the level of form and content, most likely to apply the right kind of rhetorical pressure to the person's beliefs, attitudes or reasons.

In short, efficacious public philosophy entails knowing one's audience, and knowing one's audience may be partially advanced by discursive hygiene. Accordingly, either Leiter's picture of public discourse, public philosophy and discursive hygiene is right on the broad outlines of the problem but unable to furnish conditions under which one might fruitfully pursue the former or Leiter's picture is imperfect on the broad outlines of the problem but able to furnish conditions for meaningful public discourse, public philosophy and discursive hygiene. In the end, this revised picture seems to dovetail with the moderated version of Leiter's critique upon which the author settles in the essay's closing pages. After all, he allows that logical entailments can, at times, constrain beliefs, attitudes and reasons.

That moderating influence might be further carried out by Stout's extended treatment of alternative argumentative techniques such as "moral perception" in which discursive hygiene and inference nonetheless have an important role to play. Stout (2004) scrutinizes one such exchange in the Edmund Burke-Thomas Paine controversy over democracy and custom ( $c f$. pp. 216-224). He concludes thereof that, while the emotional attitudes or affective responses constitutive of moral perception are "noninferential, they are inferentially connected to moral passions, like awe and pity, and the actions for which they serve as warrant" (Stout, 2004, p. 217). In other words, inferential relations unearthed by discursive hygiene may allow us to get a discursive grip on non-discursive factors underlying beliefs, attitudes and reasons. In the end, should we allow, with Leiter, that emotivism and tribalism are principally constitutive of attitude- and beliefformation, this does not preclude their responsiveness to the right kinds of reasons depending on the circumstances, for which discursive hygiene may yet serve a purpose and which Stout is better situated to expose. ${ }^{16}$

To conclude, while Stout sketches a stronger connection between selfknowledge and political justification than Leiter thinks reasonable, Stout is ready

\footnotetext{
${ }^{16}$ For an instance in which Stout's account outpaces Leiter's, compare Leiter's cursory remarks supra. on horror and revulsion with Stout's own analyses of anger and grief and the sacred and the horrendous in political deliberation (Stout, 2010a, Chaps. 5, 17).
} 
to work within, at least to an extent, the limits which Leiter sets. Moreover, insofar as Leiter wishes to preserve some role discursive hygiene and endorses philosophical rhetoric, he has need of a position like Stout's to flesh out his new discursive practice. ${ }^{17}$ While thick self-knowledge and justified political belief will prove challenging for most and wholly out of reach for others, this in no way prevents interlocutors in public discourse from making full use of a mixed argumentative strategy to advance the end of self-knowledge and political justification.

\section{Conclusion}

Rather than attack post-truth and post-justification head-on, we set out from the question of whether self-knowledge and political justification evince a necessary connection. To that end, we sought to test one version of that connection through its illustration in Stout (2004) as well as its implications for public philosophy. To clarify ideas, we began in the first part by laying out a framework for understanding self-knowledge as thin or thick and justification as rational commitment, justifiable belief and justified belief, the latter inspired by Pryor (2004). From there, we formulated four possible theses for the connection between self-knowledge and political justification and tentatively identified Stout (2004) with the strong and thick version whereon thick self-knowledge is necessary for political justification. In the second part, we linked the strong and thick thesis to the Stoutian justificatory devices of democratic piety, earnest storytelling and Brandomian expressive rationality. After underlining Stout's need for a strong public philosophy, we turned in the third part to Leiter's (2016) vigorous emotivist and tribalist critique of public philosophy as discursive hygiene and explored why these forces hinder public discourse, public philosophy and discursive hygiene. In the fourth and final part, we worked out two potential Stoutian replies to Leiter's critique on which public philosophy and discursive hygiene can adapt to public discourse's emotivist and tribalist tendencies. Ultimately, we judged that Leiter's critique, in its unadulterated form, undercuts the more moderate public philosophy which he envisions and lacks the tools to

\footnotetext{
${ }^{17}$ Indeed, Stout and Leiter's views seem complementary to the point that one could well have begun this paper by presenting Leiter's qualified view of public philosophy before subjecting it to Stout's own caveats rather than the chronological presentation favoured here. We owe this observation to Brandon Robshaw from a question-and-answer session.
} 
advance that vision. In light of the above, we find that Stout provides a powerful and grounded illustration of the role played by self-knowledge in political justification. All in all, the strong and thick version of the link between selfknowledge and political justification remains possible albeit fraught with the complications and hazards of actual belief-formation. Whatever might be said for the post-truth world, it does not yet appear to be post-justification, nor postpublic philosophy.

\section{References}

Bächtiger, A. and Gerber, M. (2014). 'Gentlemanly Conversation’ or Vigorous Contestation?: An Exploratory Analysis of Communication Modes in a Transnational Deliberative Poll@ (Europolis). In K. Grönlund, A. Bächtiger, and M. Setälä (Eds.), Deliberative Mini-Publics: Involving Citizens in the Democratic Process (pp. 115-134). Colchester, UK: ECPR. http://press.ecpr.eu/book_details.asp?bookTitleID=57

Brandom, R. (1994). Making It Explicit: Reasoning, Representing and Discursive Commitment. Cambridge, MA: Harvard University Press. http://www.hup.harvard.edu/catalog.php?isbn=9780674543300

Brandom, R. (2000). Articulating Reasons: An Introduction to Inferentialism. Cambridge, MA: Harvard University Press. http://www.hup.harvard.edu/catalog.php?isbn=9780674006928

Dryzek, J.S. (2000). Deliberative Democracy and Beyond: Liberals, Critics, Contestations. Oxford, UK: Oxford University Press. http://www.oxfordscholarship.com/view/10.1093/019925043X.o01.0001/acpr of-9780199250431

Frohlich, N., Oppenheimer, J.A., \& Eavey, C.L. (1987). Choice of principles of distributive justice in experimental groups. American Journal of Political Science, 31(3), 606-636. https://www.jstor.org/stable/2111285?seq=1\#page_scan_tab_contents

Lafont, C. (2013). Religion and the Public Sphere: What are the Deliberative Obligations of Democratic Citizenship?. In C. Calhoun, E. Mendieta, \& J. VanAntwerpen (Eds.), Habermas and Religion (pp. 230-248). 
Cambridge, UK: Polity Press.

http://eu.wiley.com/WileyCDA/WileyTitle/productCd-074565326X.html

Leiter, B. (2016). The Paradoxes of Public Philosophy. Indian Journal of Legal Theory, 1(1), 51-64.

http://centreforlegaltheory.in/Mindfields_files/issues/issue1.pdf

Pryor, J. (2004). What's Wrong with Moore's Argument?. Philosophical Issues, 14(1), 349-378. http://onlinelibrary.wiley.com/doi/10.1111/j.15336077.2004.00034.x/abstract

Rawls, J. (1971). A Theory of Justice. Cambridge, MA: Harvard University Press. http://www.hup.harvard.edu/catalog.php?isbn=9780674000780

Rawls, J. (1993). Political Liberalism. New York, NY: Columbia University Press. https://cup.columbia.edu/book/political-liberalism/9780231130899

Stout, J. (1988). Ethics after Babel: The Languages of Morals and Their Discontents. Boston, MA: Beacon Press. http://press.princeton.edu/titles/7049.html

Stout, J. (2004). Democracy and Tradition. Princeton, NJ: Princeton University Press. http://press.princeton.edu/titles/7667.html

Stout, J. (2010a). Blessed are the Organized: Grassroots Democracy in America. Princeton, NJ: Princeton University Press. http://press.princeton.edu/titles/9279.html

Stout, J. (2010b). Rorty on Religion and Politics. In R.E. Auxier \& L.E. Hahn (Eds.), The Philosophy of Richard Rorty (pp. 523-545). Chicago, IL: Open Court Press. http://www.opencourtbooks.com/books_n/philosophy_rorty.htm 